\title{
Geofluids Assessment of the Ayub and Shafa Hot Springs in Kopet-Dagh Zone (NE Iran): An Isotopic Geochemistry Approach
}

\author{
Hossein Mohammadzadeh and Majid Kazemi \\ Groundwater Research Center (GRC), Department of Geology, Faculty of Science, Ferdowsi University of Mashhad, \\ P.O. Box 91775-1436, Mashhad, Iran
}

Correspondence should be addressed to Hossein Mohammadzadeh; mohammadzadeh@um.ac.ir

Received 8 September 2016; Accepted 29 January 2017; Published 12 March 2017

Academic Editor: Marco Petitta

Copyright (C) 2017 Hossein Mohammadzadeh and Majid Kazemi. This is an open access article distributed under the Creative Commons Attribution License, which permits unrestricted use, distribution, and reproduction in any medium, provided the original work is properly cited.

Geothermal energy has a wide range of uses in our life. It is very important to characterize the temperature and the depth of geothermal reservoirs. The aim of this paper is the determination of type, origin source of water temperature, and depth of water circulation in the Ayub-Peighambar and Shafa (AP and SH) hot springs, located in NE Iran, using hydrogeochemistry and environmental isotopes $\left({ }^{2} \mathrm{H}\right.$ and $\left.{ }^{18} \mathrm{O}\right)$. AP hot spring has elevated temperature $\left(36-40^{\circ} \mathrm{C}\right)$ and as such is very important for balneotherapy and geotourism industry purposes. The average values of $\delta^{18} \mathrm{O}$ and $\delta^{2} \mathrm{H}$ for this hot spring $(-10 \%$ and $-73 \%$, resp.) are analogous to that of geothermal and meteoric waters. This indicates that the heat source cannot be related to volcanic activities (with average $\delta^{18} \mathrm{O}$ value of about $5 \%$ ) and it is most probably associated with geothermal gradient with deep circulation of groundwater through faults. Based on Na-K geothermometers coupled with isotopic $\left({ }^{18} \mathrm{O}\right.$ and $\left.{ }^{2} \mathrm{H}\right)$ geochemistry the temperature of the AP geothermal reservoir was estimated to be in the range of $100-150^{\circ} \mathrm{C}$ with $3-5$ and 4.2 kilometres' depth, respectively. Chemically, the AP samples are $\mathrm{CaSO}_{4}$ facies with a chemically homogeneous source and steam heated waters type.

\section{Introduction}

Characteristics of springs (especially hot springs) in orogenic regions are due to the interaction between water, the lithosphere, and environmental conditions like lithology, pathways, residence time underground, and many other factors. The origin of elevated temperatures in hydrothermal reservoirs (hot/warm springs) can be due to the geothermal gradient with deep circulation of groundwater through faults, chemical reactions (e.g., in evaporates and oil field brines), heat produced through radioactive decay of longlived radioactive material (isotopes), and mixing of meteoric water with magmatic water or volcanic vapour in volcanic area [1-11]. The hydrothermal phenomenon most often occurs where the released water and vapour are related to regional volcanic activities. The geothermal heat transfer to the ground surface occurs through aqueous and magmatic/volcanic systems. In an aqueous system, cold surface water can penetrate to depth through deep faults/fractures, where convective currents cause the boiling of water. Subsequently the high temperature groundwater flows upward creating a hydrothermal system on or near the ground surface as hot springs or thermal groundwater discharge within an aquifer [12]. In a geothermal field, an aqueous system can be seen as hot spring, geyser, and mudpot subsystems. Understanding the origin of hydrothermal fluids and the reason for the elevation of temperature is a very important step in revealing the temperature and pressure conditions of the underground reservoirs [13]. To determine the reason and origin of the temperature/heat in a geothermal field, several methods such as remote sensing, geological investigation, geophysical survey, thermal anomalies measurements, and hydrochemical and isotopic method can be applied [14]. Today oxygen and hydrogen isotopes are widely used in geothermal studies to determine the origin and history of geothermal fluids and often serve as natural tracers for the 

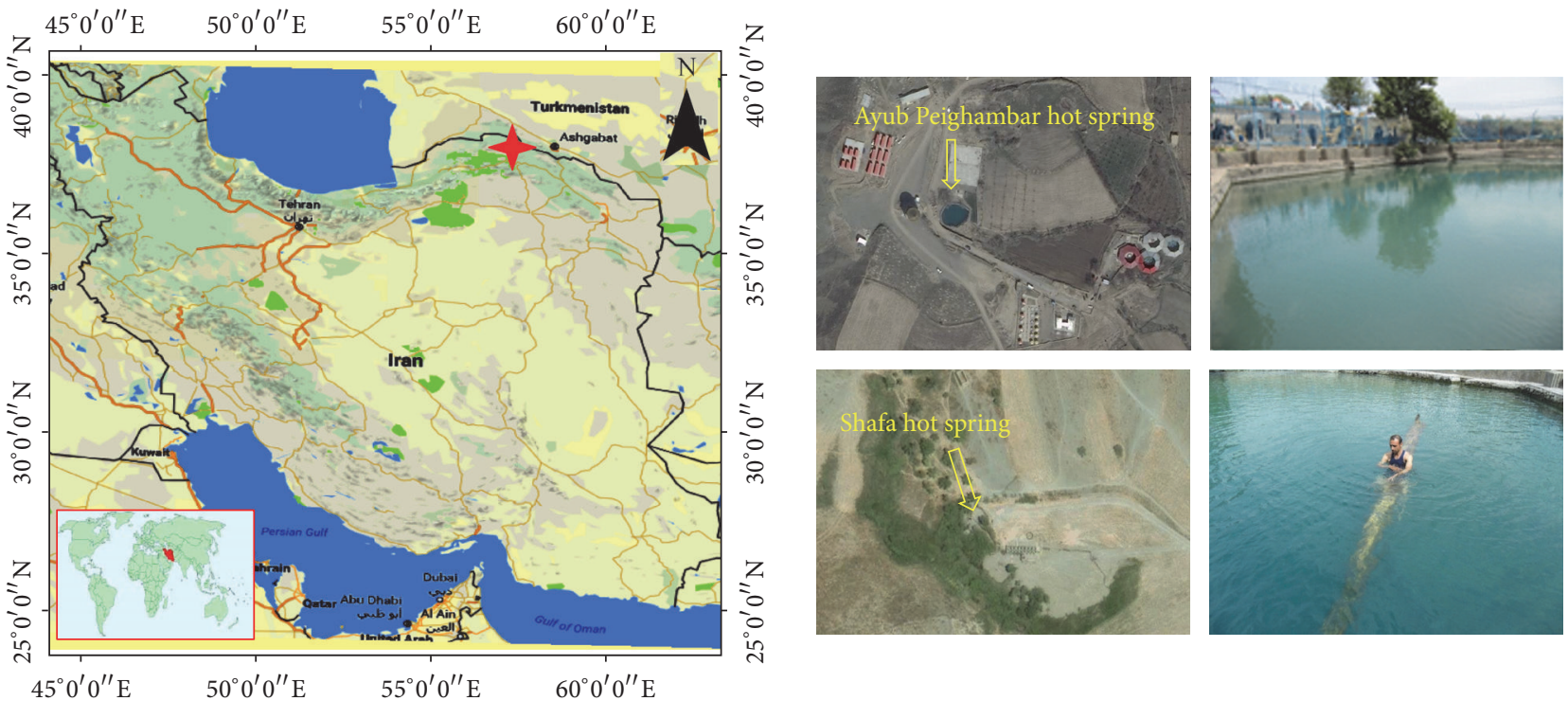

FIGURE 1: The study area and the locations of the Ayub-Peighambar and Shafa (AP and SH) hot springs.

provenance of geothermal water. Most geothermal systems are recharged by meteoric waters and if recharging from shallower groundwater these systems have isotope compositions consistent with local meteoric precipitation [15]. The main objective of this paper is to determine the geothermal reservoir characteristics (type, origin, temperature, and depth of circulation) of Ayub-Peighambar and Shafa (AP and SH) hot springs, in the NE of Iran, using geothermometers and environmental ${ }^{2} \mathrm{H}$ and ${ }^{18} \mathrm{O}$ isotopes along with geological and thermal anomalies data of the study area.

\section{Sampling Locations and Geology of the Study Area}

The $\mathrm{AP}$ and $\mathrm{SH}$ hot springs, with a temperature range of 36 to $40^{\circ} \mathrm{C}$, are located in the NE of Iran (Figure 1). Field parameter measurement locations and sampling points are illustrated in Figure 2(a). The geological map of the study area was generated using field observations, satellite images, and remote sensing techniques (Figure 2(a)). As illustrated on the geological map, various sedimentary lithological units including massive limestone (Tirgan Formation), marl as pencil marl (Sarcheshmeh Formation), marl-shale (Sanganeh Formation), and sandstone-shale with glauconite (Aitamir Formation) have outcropped in the study area. These formations make the Asiazow anticline with a 15-degree plunge to the west, thrusting and faulting (Figure 2(b)). By oxidation of pyrite, as clearly indicated in thin sections of both Sarcheshmeh and Aitamir Formations, dissolved sulfate was produced [17], which in turn can be reduced through microbial and thermal reduction process (Hill, 1987; [18]), which finally results in $\mathrm{H}_{2} \mathrm{SO}_{4}$ production in the groundwater $[18,19]$.

Travertine around AP hot spring is evidence of a long discharge history at this spring (Figure 3). This indicates that the water of AP hot spring has previously moved upward through faults where the surface temperature and pressure conditions led to oversaturation of the water with respect to carbonate minerals $\left(\mathrm{CaCO}_{3}\right)$ which in turn caused travertine precipitation. This is confirmed by the presence of calcite and aragonite (usually aragonite forming in deep conditions rather than calcite) structures in thin sections and in Scanning Electron Microscope (SEM) images (Figure 3). The XRay Fluorescence (XRF) analysis of travertine indicates that $\mathrm{CaO}$ contains $55 \%$ of travertine and Atomic Absorption Spectrophotometry (AAS) and Energy Dispersive Spectrometer (EDX) results show that calcium (with 27\%) is the major cation in AP travertine (Figure 3). The existence of a large amount of voids in the travertine can be seen clearly in both hand specimens and thin sections (Figure 3), indicating that $\mathrm{CO}_{2}$ was escaping during formation of this thermogenic travertine. There is no evidence for volcanic activities or existence of intrusive igneous rocks, as confirmed by the field observations and reported by previously report [20].

\section{Material and Methods}

Water samples were collected in polyethylene $25 \mathrm{~mL}$ bottles, from AP and SH hot springs during 2013-2014. All samples were filtered using $0.45 \mu \mathrm{m}$ membrane and the cation samples were acidified using concentrated $\mathrm{HNO}_{3}$ acid. Field parameters, T, pH, Eh, EC, and TDS, were measured during sampling. The geochemical analyses of main cations and anions and the isotopic analyses of ${ }^{18} \mathrm{O}$ and ${ }^{2} \mathrm{H}$ in water were performed at the geochemistry and G. G. Hatch Stable Isotope laboratories at the University of Ottawa. Geological formations of the study area were investigated using available maps, remote sensing with satellite images, and field observation. The sediment samples were collected from the AP hot spring frontal pool and their mineral contents were determined from thin sections and binocular microscope. All AAS, XRF, SEM, and EDX analyses on travertine samples were done at the Ferdowsi University 


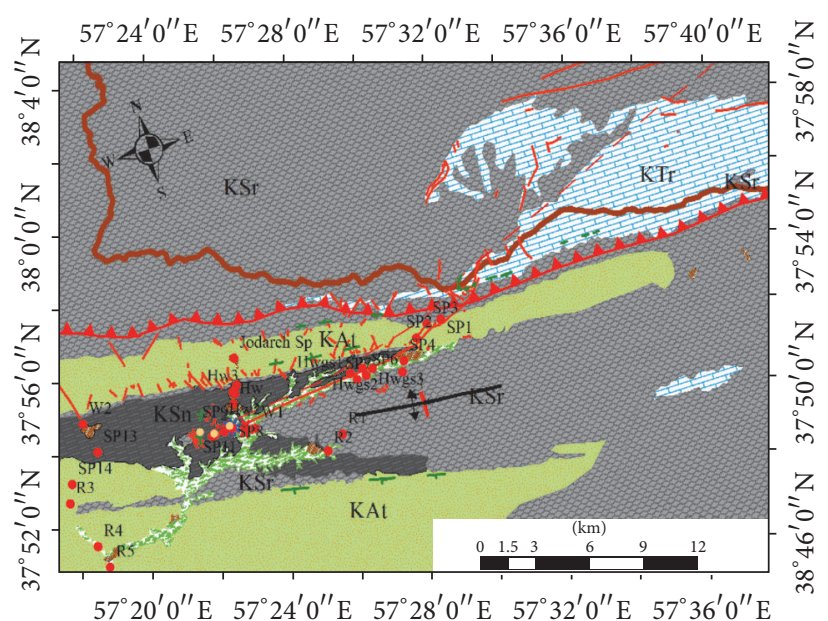

$\begin{array}{ll}\text { * AP and SH hot springs } & \text { Farm land } \\ \text { * Germab spring } & \\ \text { * Ayub cold spring } & -1 \text {.lage } \\ \text { * Travertine point } & - \text { Faul anticline } \\ \text { - Bed slope } & - \text { Hidden fault } \\ \text { International boundary } & \ldots \text { Trust fault } \\ & \text { (Iran-Turkmenistan) }\end{array}$

Name Fm. main lithology

Aitamir Fm.: sandstone-shale with glauconite
Sanganeh Fm.: marl-shale
Sarcheshmeh Fm.: pencil marl
Tiّn

(a)

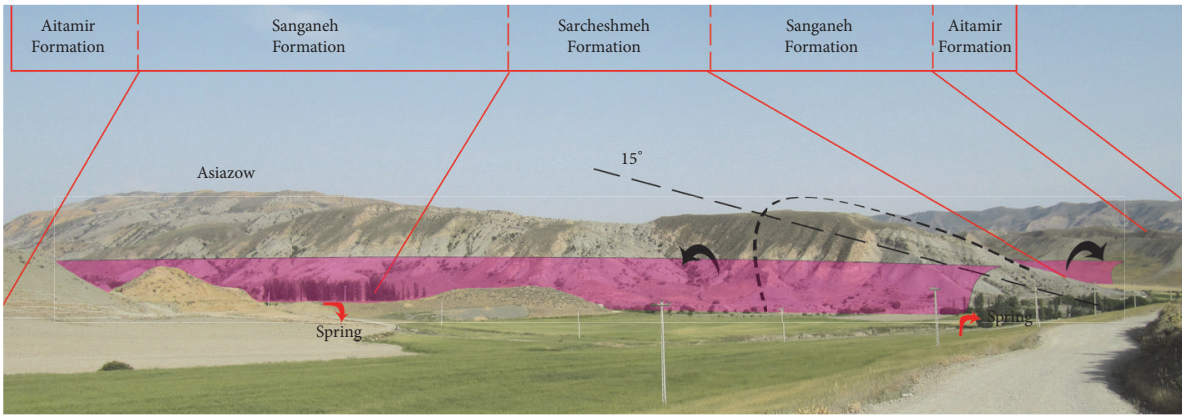

(A)

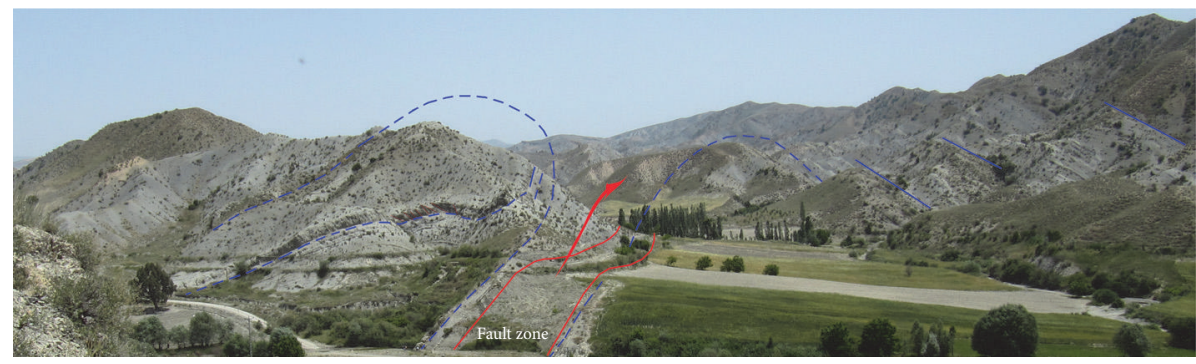

(B)

(b)

Figure 2: (a) Sampling locations and the geological map of the study area and (b) the simulated photographs of (A) Kuh-e-Asiazow anticline; the fold axis with E-W trend has $\sim 15^{\circ}$ plunge to the west. The thrust plane is shown as pink sheets; the view is to the southeast, and (B) a fold-thrust fault in Sanganeh shale and marl, view is to the east [16]. 


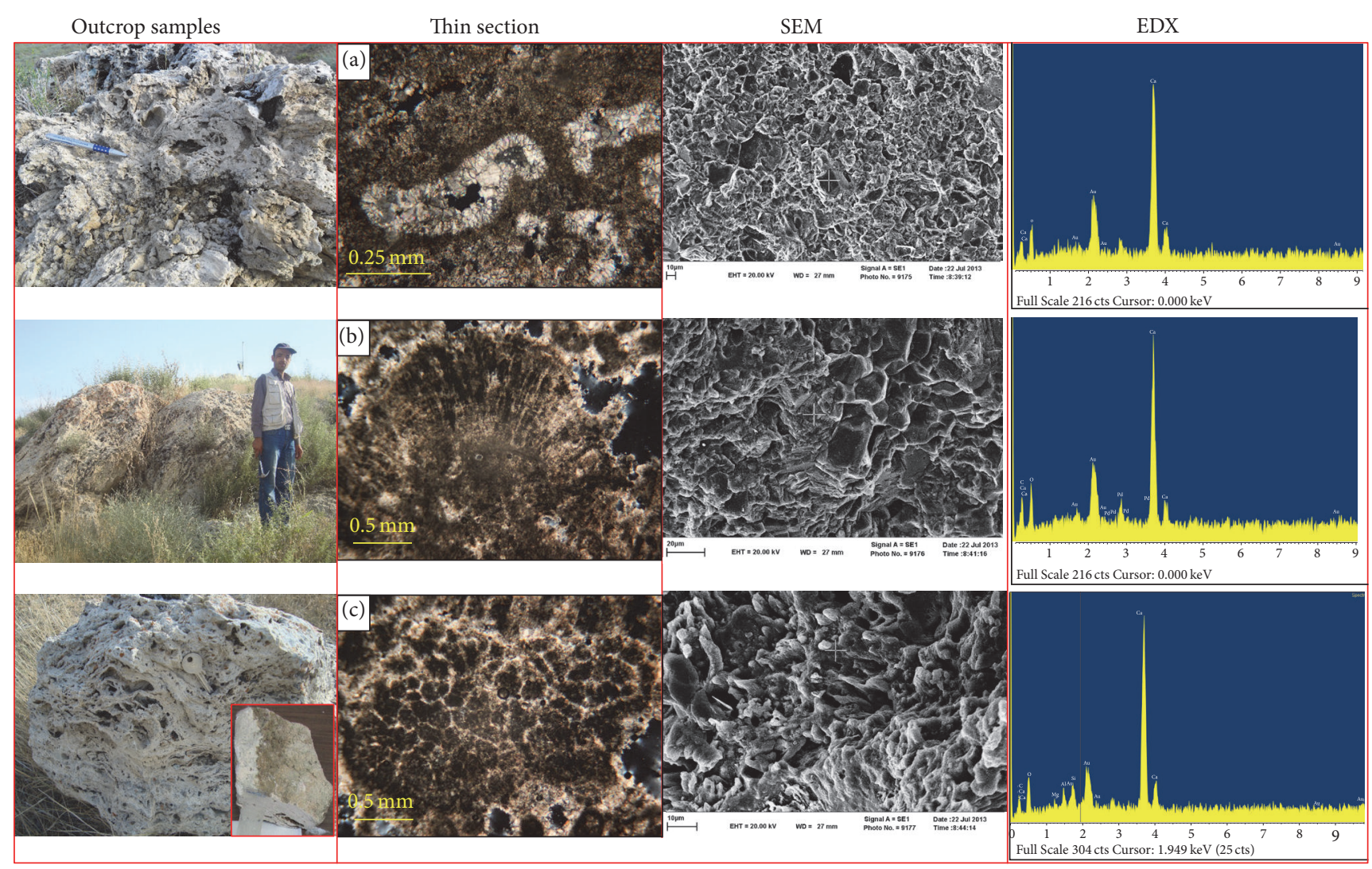

FIgURE 3: Travertines hand samples, thin sections, SEM images, and EDX result.

of Mashhad. The geothermometry of water samples was determined using Aq.QA hydrochemical software [21] and cation geothermometers $(\mathrm{Na}-\mathrm{K})$ coupled with isotopic $\left({ }^{18} \mathrm{O}\right.$ and ${ }^{2} \mathrm{H}$ ) geochemistry.

\section{Results and Discussion}

The measured field parameters and major ion concentrations of groundwater samples are listed in Table 1. The origin and type of water and geothermal reservoir characteristics (temperature and depth) of AP and SH hot spring were investigated using geochemistry and geological studies, geothermometers, and environmental ${ }^{2} \mathrm{H}$ and ${ }^{18} \mathrm{O}$ isotopes.

4.1. The Origin and Type of Water in the AP and SH Hot Spring. Based on piper diagram AP and $\mathrm{SH}$ hot springs fall into the $\mathrm{CaSO}_{4}$ facies (Figure 4) and according to $\mathrm{Cl}-\mathrm{HCO}_{3}$ $\mathrm{SO}_{4}$ diagram (Figure 5) we have distinguished mature waters (high content of $\mathrm{Cl}$ and is saline), peripheral and shallow waters $\left(\mathrm{HCO}_{3}\right.$ is more than $\left.50 \%\right)$, steam heated waters $\left(\mathrm{SO}_{4}\right.$ is more than $50 \%$ and $\mathrm{HCO}_{3}>\mathrm{Cl}$ ), and magmatic and volcanic waters $\left(\mathrm{HCO}_{3} \approx 0\right.$, high $\mathrm{SO}_{4}$ and sulfate and chloride type) [22]. Chemically, the AP and SH hot springs samples have the same chemical composition as a chemically homogeneous source and are of the steam heated water type. These samples have considerable concentrations of $\mathrm{HCO}_{3}, \mathrm{Ca}$, and $\mathrm{Mg}$ with $\mathrm{Ca}-\mathrm{SO}_{4}$ type, indicating deep circulation of meteoric water through the carbonate formation and available deep faults in study area. The increasing of water temperature is probably due to deep circulation and exothermic chemical reactions (probably within the Shourijeh Formation with anhydrite and gypsum). However, a partial melting zone, which emerged through convection currents and faults in the axis of Asiazow anticline, cannot be ruled out.

4.2. Deep Water Circulation Evidence in Quartz of AP Sediment, Thermal Anomalies, and $\mathrm{CO}_{2}$ Gas. Since there is no volcanic activity in the area [20], the possibility of a volcanic source for the AP spring's hydrothermal reservoir has been rejected. The existence of travertine around AP spring provides insight into the circulation of water through faults in the past and present. Cold meteoric waters penetrated and dissolved deep Tirgan limestone formations and then became highly enriched in bicarbonate $\left(\mathrm{HCO}_{3}\right)$ and sulfate $\left(\mathrm{SO}_{4}\right)$ (due to reduction of mineral sulfates by bacteria with carbonate mineral dissolution at depth) and precipitated/or not precipitated $\mathrm{CaCO}_{3}$ on the ground surface, depending on the $\mathrm{pH}$ and $\mathrm{Eh}$ of the spring water. This porous thermogenic travertine has had very high amount of $\mathrm{CO}_{2}$ which resulted from deep circulation, exothermic chemical reactions, and dissolution of limestone by sulfuric acid. The thermal anomaly map of the study area, prepared based on temperature of local springs' water (Table 1), indicates that the AP and SH hot springs in the study area have the most thermal anomalies (Figure 6). These thermal anomalies are 


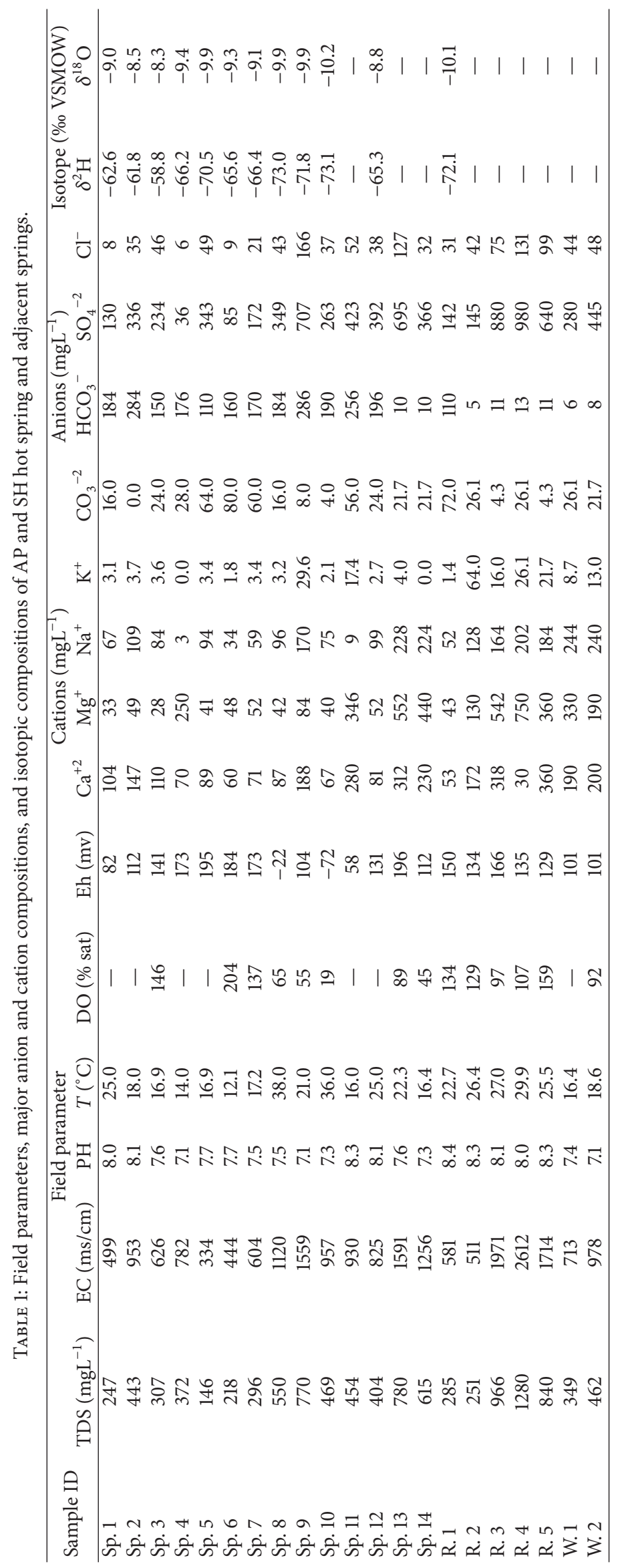




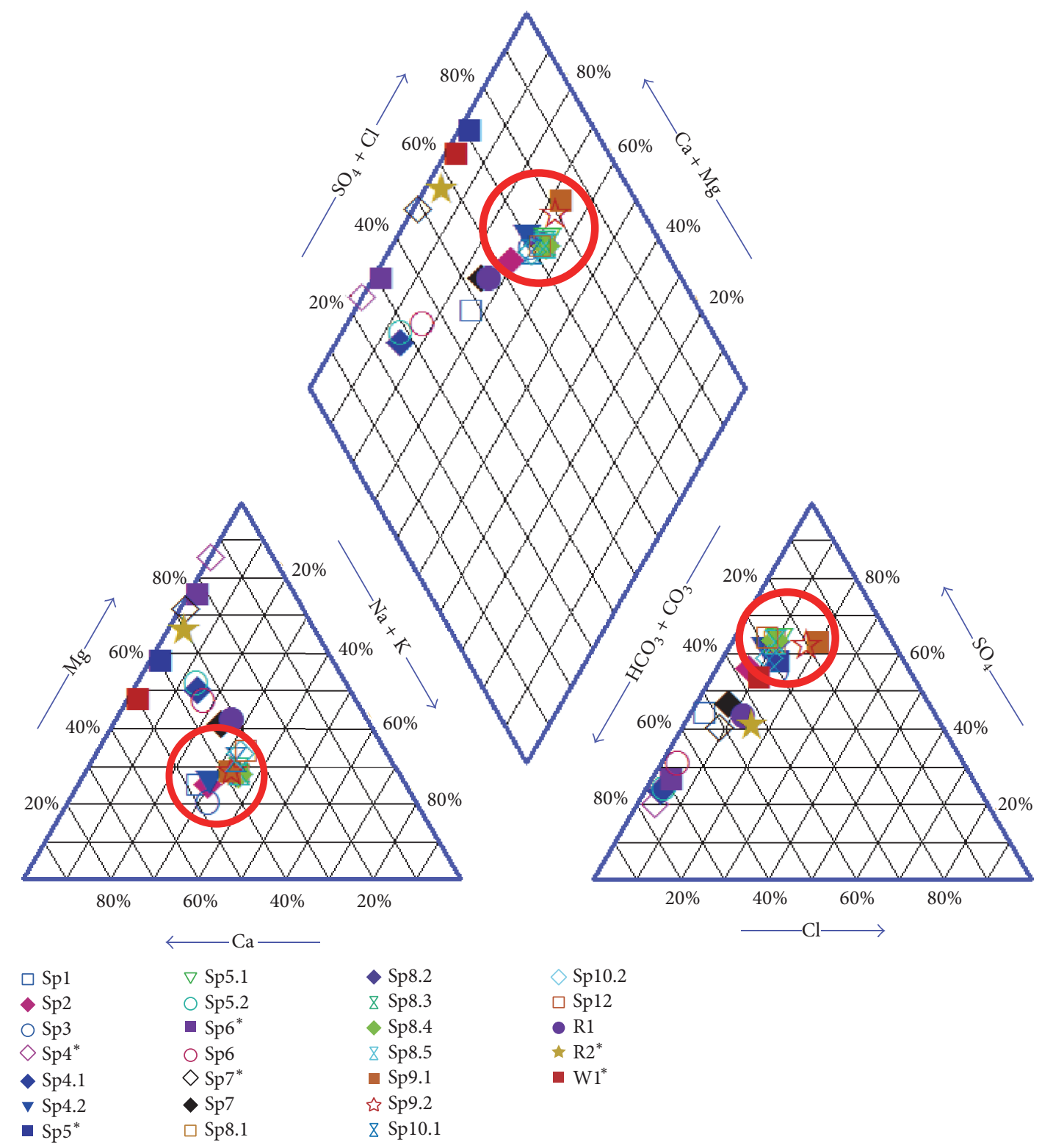

FIGURE 4: Situation of water samples in the study area on a piper diagram (red circles detect AP and SH hot spring).

caused by tectonically tensional conditions, which can be confirmed by the presence of travertine as well as joints and faults in the area (e.g., [23]; Liu et al., 2003). The sedimentary petrography of AP hot spring indicates quartz and rimburned biotite has been altered to chlorite, via chloritization, which is characteristic of igneous biotite. Although assembled minerals of green chlorite, opaque mineral (pyrite), amphibole, and glauconite can be seen in thin sections (Figure 7), igneous biotite is reported for the first time in this research and needs further investigation. Large amounts of quartz in pool sediments and also in thin section of this sediment confirmed deep circulation of water. The amount of $\mathrm{CO}_{2}$ that dissolved in AP hot spring is $9.25 \mathrm{mg} / \mathrm{L}$ with a little $\mathrm{H}_{2} \mathrm{~S}$, exempt of bubbles that escaped [24], indicating deep circulation of water through the deep faults [25] that were generated by sulfuric acid in phreatic zone.

4.3. Temperature and Depth Measurements of the Hydrothermal Reservoirs Using Geothermometers. The temperature of hydrothermal reservoirs can be determined using geothermometry [26]. Since geothermometers equilibrate with their surrounding environments under certain temperature and pressure, their equilibrium concentrations in water (from hot springs, soil, and rock) are applied to determine the thermodynamic equilibrium temperature and pressure conditions $[26,27]$. This method is very useful in areas without drilled boreholes/wells and it is applicable for initial studies in exploration geothermal fields. To estimate the ranges 


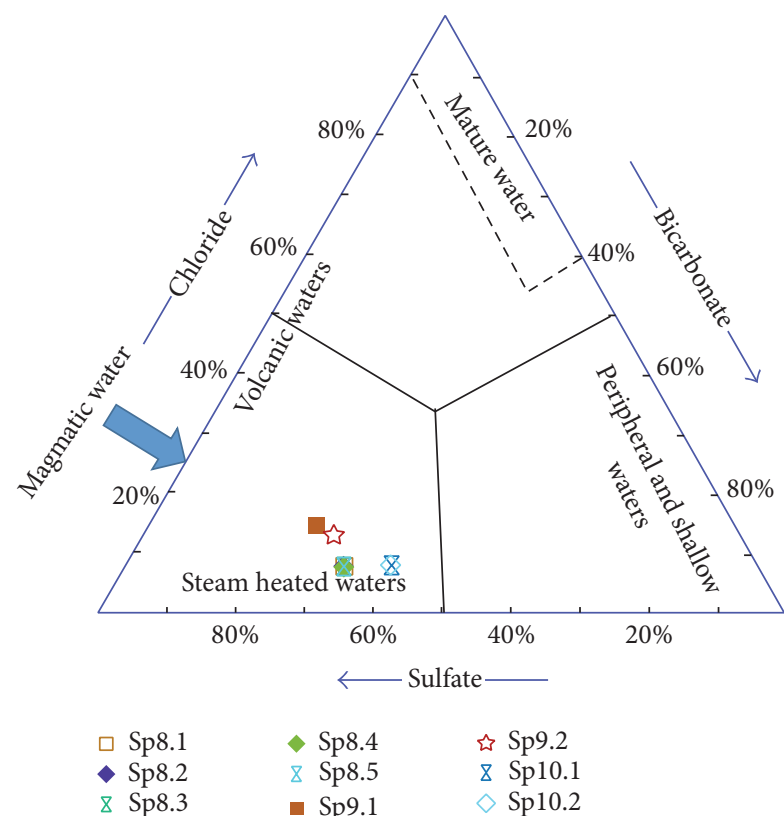

(a)

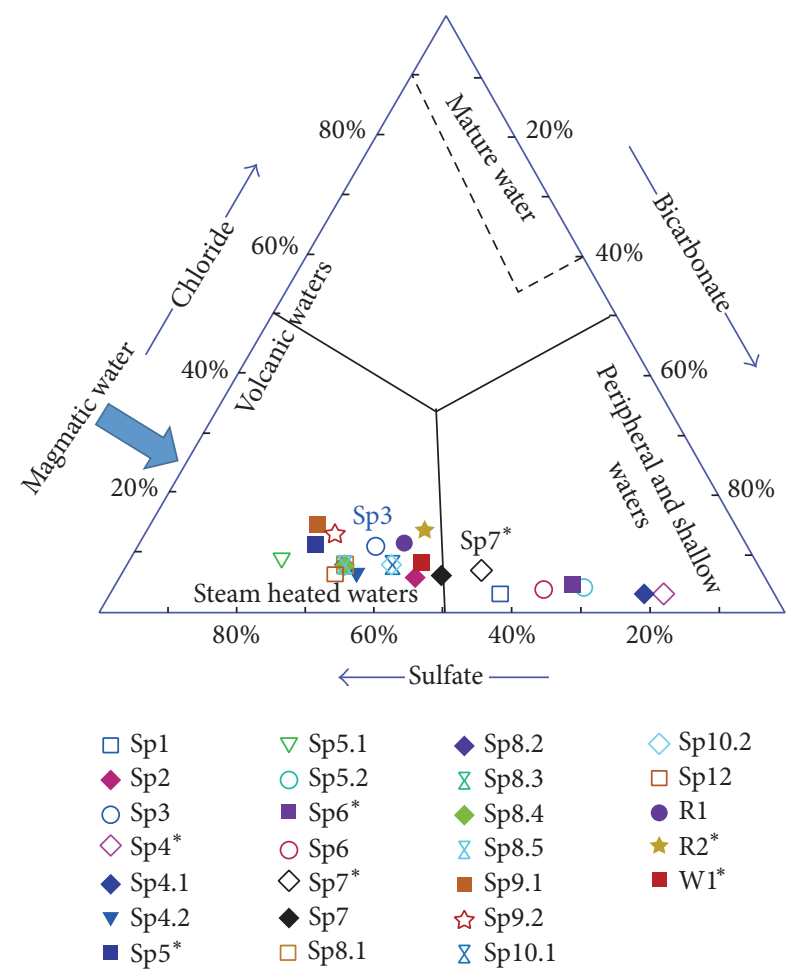

(b)

FIgURE 5: Triangular $\mathrm{Cl}-\mathrm{HCO}_{3}-\mathrm{SO}_{4}$ diagram that detects source waters of $\mathrm{AP}$ and $\mathrm{SH}$ hot springs (a) and other water resources (b) in study area.

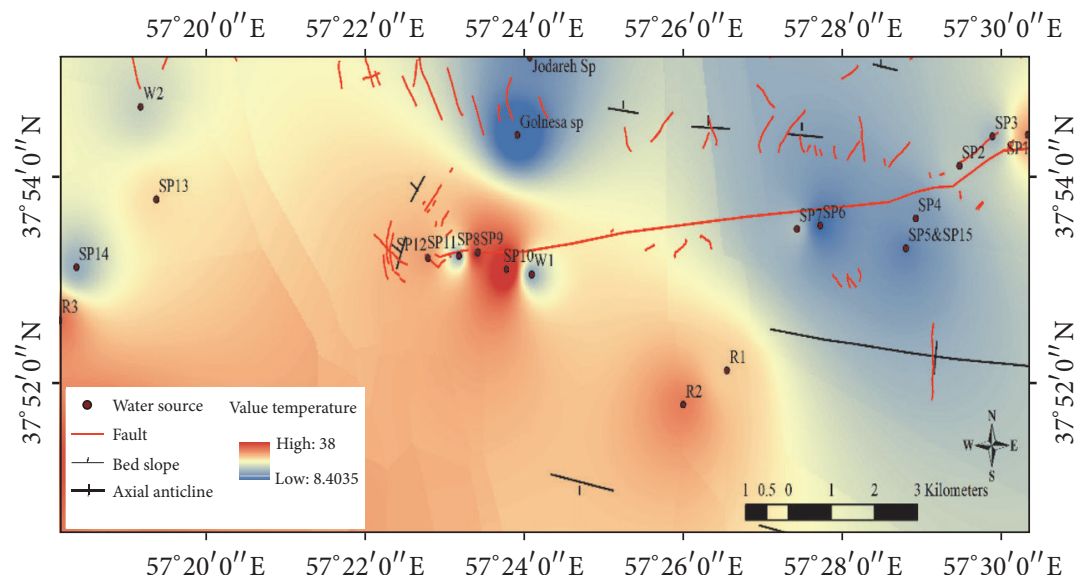

FIGURE 6: The thermal anomalies map of the study area.

of temperature in a geothermal reservoir, a large suite of geothermometry tools (minerals, elements, and chemical composition such as silica $\left(\mathrm{SiO}_{2}\right)$, cations $(\mathrm{Na}, \mathrm{K}$, and $\mathrm{Li})$, and gases $\left(\mathrm{H}_{2} \mathrm{~S}, \mathrm{CO}_{2}, \mathrm{H}_{2}, \mathrm{CO}_{2} / \mathrm{H}_{2}\right.$, and $\left.\left.\mathrm{H}_{2} \mathrm{~S} / \mathrm{H}_{2}\right)\right)$ can be used $[15,26,28]$. The equilibrium concentrations of $\mathrm{Na}$ and $\mathrm{K}$ in aqueous and solid feldspar phases (1) strongly depend on temperature. Therefore, the Na-K geothermometer can be applied for both [29-31] hot water $\left(250<T<300^{\circ} \mathrm{C}\right)$ and very hot water $\left(T>300^{\circ} \mathrm{C}\right)[15,29]$.

Based on chemical composition of the water, the temperature of AP hot springs reservoirs were estimated using the $\mathrm{Na}-\mathrm{K}$ geothermometer and (2). Also the temperatures were estimated using Aq.QA software by defining $\mathrm{Na}-\mathrm{K}$ and $\mathrm{SiO}_{2}$ as geothermometers. The depth of geothermal reservoir of these springs was calculated using (3) [32] and all estimated temperature and depth are listed in Table 2.

$$
\begin{aligned}
\mathrm{K}^{+}+\mathrm{Na} \text {-feldspar } & =\mathrm{K} \text {-feldspar }+\mathrm{Na}^{+} \\
T^{\circ} \mathrm{C}(\mathrm{Na}-\mathrm{K}) & =\left[\frac{933}{0.933+\log (\mathrm{Na} / \mathrm{K})}\right]-273.15 \\
D & =\frac{(\mathrm{Tg}-\mathrm{Ts})}{\Delta G} .
\end{aligned}
$$


TABLE 2: Temperatures and depths of hydrothermal reservoirs for AP and SH hot springs, calculated based on Na-K geothermometers [28, 31], Aq.QA hydrochemical software [21], and isotopic method.

\begin{tabular}{|c|c|c|c|c|c|c|c|}
\hline & \multirow[b]{2}{*}{ Sp8.1 } & \multicolumn{3}{|c|}{ Ayub Peighambar hot spring } & \multicolumn{3}{|c|}{ Shafa hot spring } \\
\hline & & Sp8.2 & Sp8.3 & Sp8.4 & Sp8.5 & Sp10.1 & Sp10.2 \\
\hline \multicolumn{8}{|c|}{ Using Aq.QA hydrogeochemistry software } \\
\hline Temperature (Na-K) & $<150$ & $<150$ & $<150$ & $<150$ & $<150$ & $<150$ & $<150$ \\
\hline Depth $(\mathrm{km})^{*}$ & $<5$ & $<5$ & $<5$ & $<5$ & $<5$ & $<5$ & $<5$ \\
\hline Depth $(\mathrm{km})^{* *}$ & 4.65 & 4.65 & 4.65 & 4.65 & 4.65 & 4.65 & 4.65 \\
\hline \multicolumn{8}{|c|}{ Using Mohammadi’s [31] method } \\
\hline Temperature (Na-K) & 113 & 114 & 114 & 110 & 111 & 101 & 101 \\
\hline Depth $(\mathrm{km})^{*}$ & 3.76 & 3.80 & 3.82 & 3.66 & 3.70 & 3.36 & 3.36 \\
\hline Depth $(\mathrm{km})^{* *}$ & 3.42 & 3.45 & 3.47 & 3.31 & 3.35 & 3.02 & 3.02 \\
\hline \multicolumn{8}{|c|}{ Isotopic method (all isotope data in \%o VSMOW) } \\
\hline & $\begin{array}{l}\text { In cold } \\
\text { spring }\end{array}$ & $\begin{array}{l}\text { In hot } \\
\text { spring }\end{array}$ & $\begin{array}{c}\text { Differenc } \\
(\Delta)\end{array}$ & & & & Max depth $(\mathrm{km})$ of water circulation \\
\hline$\delta^{18} \mathrm{O}$ & -9.29 & -9.97 & -0.68 & & & & 4.16 \\
\hline$\delta^{2} \mathrm{H}$ & -66.47 & -73.0 & -6.53 & & & & 3.66 \\
\hline
\end{tabular}

${ }^{*}$ Based on general law of geothermal gradient $\left(30^{\circ} \mathrm{C} / \mathrm{km}\right)$.

${ }^{* *}$ Using Marques et al. [32] approach.

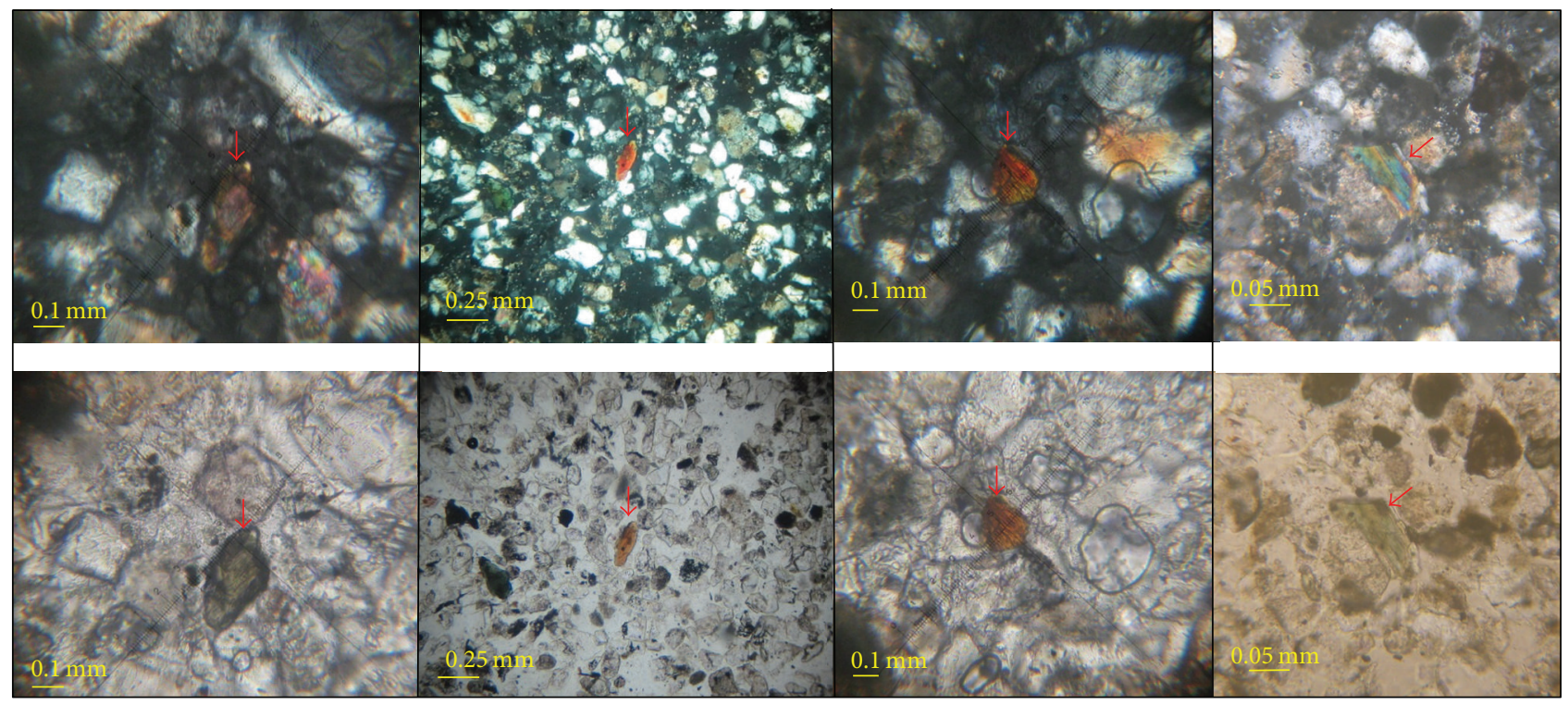

FIGURE 7: Biotite in matrix of quartz in AP spring's sediment.

Here, $D$ is the depth of reservoir $(\mathrm{km}), T g$ is the calculated temperature by geothermometers, and $T s$ refer to the average annual temperature $\left(10.4^{\circ} \mathrm{C}\right.$ which is calculated by Domarton and Amberege methods [34]). Also $\Delta G$ is the geothermal gradient $\left(0.03^{\circ} \mathrm{C}\right.$ per 1 meter $)$.

4.4. Heat Source Determination Using ${ }^{18} \mathrm{O}$ and ${ }^{2} \mathrm{H}$ Isotopes. Based on $\delta^{18} \mathrm{O}$ and $\delta^{2} \mathrm{H}$ values of a geothermal water, the heat source of the water may be determined [14]. The $\delta^{18} \mathrm{O}$ and $\delta^{2} \mathrm{H}$ values of AP and SH hot springs are plotted within the range of geothermal and meteoric waters (Figure 8). The average $\delta^{18} \mathrm{O}$ values of the $\mathrm{AP}$ and $\mathrm{SH}$ hot springs
$(-10 \%$, Figure 8$)$ indicate that the heat source cannot be related to volcanic activities (with $\delta^{18} \mathrm{O}$ value of about 5\%o) and therefore the geothermal gradient is the primary heat source. Meteoric water, by penetrating to depth through faults/fractures, is heated and altered to a geothermal water, subsequently rising and discharge at the land surface. The deuterium content of these springs (average of $-73 \%$, $n=$ 21 ) is within the range of granitic and metamorphic rocks $(-40 \%$ o to $-90 \%$, Figure $8(\mathrm{~b}))$, which is probably due to partial melting and alteration in Kopet-Dagh bedrock that resulted in increasing temperature in spring water (reference for partial melting and alteration). Although this can be 


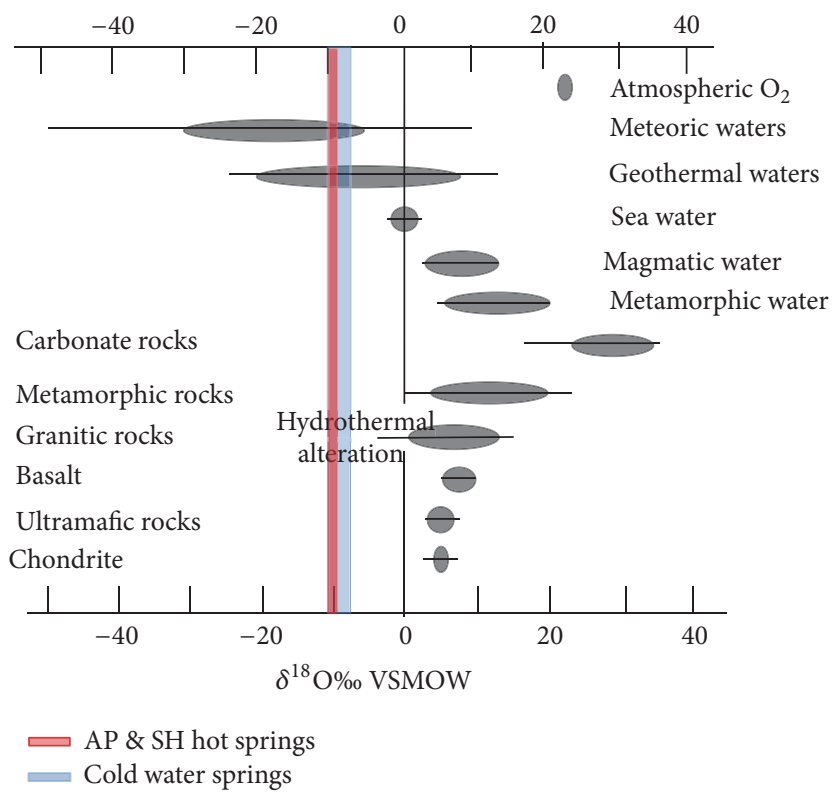

(a)

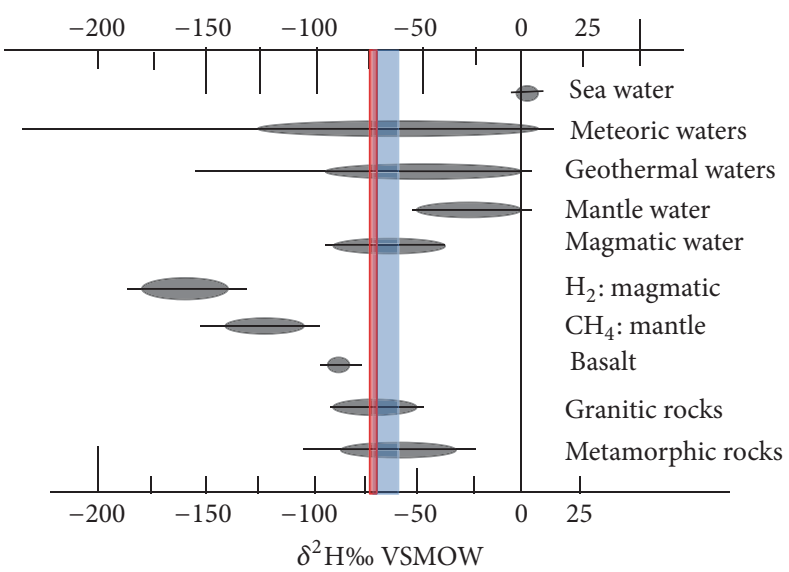

$\simeq \mathrm{AP} \& \mathrm{SH}$ hot springs

Cold water springs

(b)

Figure 8: The range of $\delta^{18} \mathrm{O}(\mathrm{a})$ and $\delta^{2} \mathrm{H}(\mathrm{b})$ compositions in various crustal rock and water types [33] and the range of $\delta^{18} \mathrm{O}$ and $\delta^{2} \mathrm{H}$ in the AP hot spring and cold water springs in the study area.

confirmed with the existence of biotite in AP hot spring sediment, it needs more investigation.

4.5. Calculating the Depth of Water Circulation Using ${ }^{18} \mathrm{O}$ and ${ }^{2} H$ Isotopes. The depth of water circulation in the AP hot spring reservoir was determined using $\delta^{18} \mathrm{O}$ and $\delta^{2} \mathrm{H}$ isotopic compositions and (4) [35]. The maximum depth of water circulation in AP spring is approximately 5 kilometres (Table 2).

$$
\begin{aligned}
d(\mathrm{H}) & =-0.397 \Delta^{2} \mathrm{H}+1.064 \\
\Delta^{2} \mathrm{H} & =\delta^{2} \mathrm{H}_{\text {hotspring }}-\delta^{2} \mathrm{H}_{\text {coldspring }} \\
d(\mathrm{O}) & =-1.470 \Delta^{18} \mathrm{O}+3.162 \\
\Delta^{18} \mathrm{O} & =\delta^{18} \mathrm{O}_{\text {hotspring }}-\delta^{18} \mathrm{O}_{\text {coldspring, }}
\end{aligned}
$$

where $d$ is the depth of water circulation (in km) and $\Delta$ is $\delta^{18} \mathrm{O}$ or $\delta^{2} \mathrm{H}$ isotopes difference (in \%o) between hot water and cold water spring in the study area.

The DIC and DOC concentrations in AP hot spring are 91 and $3 \mathrm{mgL}^{-1}$, respectively. The high amount of DIC and its enriched $\delta^{13} \mathrm{C}$ value (-1.3\%o VDPB) indicate carbonate dissolution in the geothermally heated water flow path. As illustrated in Figure 9, the ${ }^{13} \mathrm{C}$-DIC isotope in AP spring is analogous to the range of ${ }^{13} \mathrm{C}$ derived from carbonate dissolution [36]. Therefore, the Tirgan marine carbonate formation (with $\delta^{13} \mathrm{C}$ content about $0 \%$ ) is probably the main recharge source of the AP spring. Meteoric waters percolated through the Tirgan limestone via faults and discharged from the AP spring after passing through underground karst 


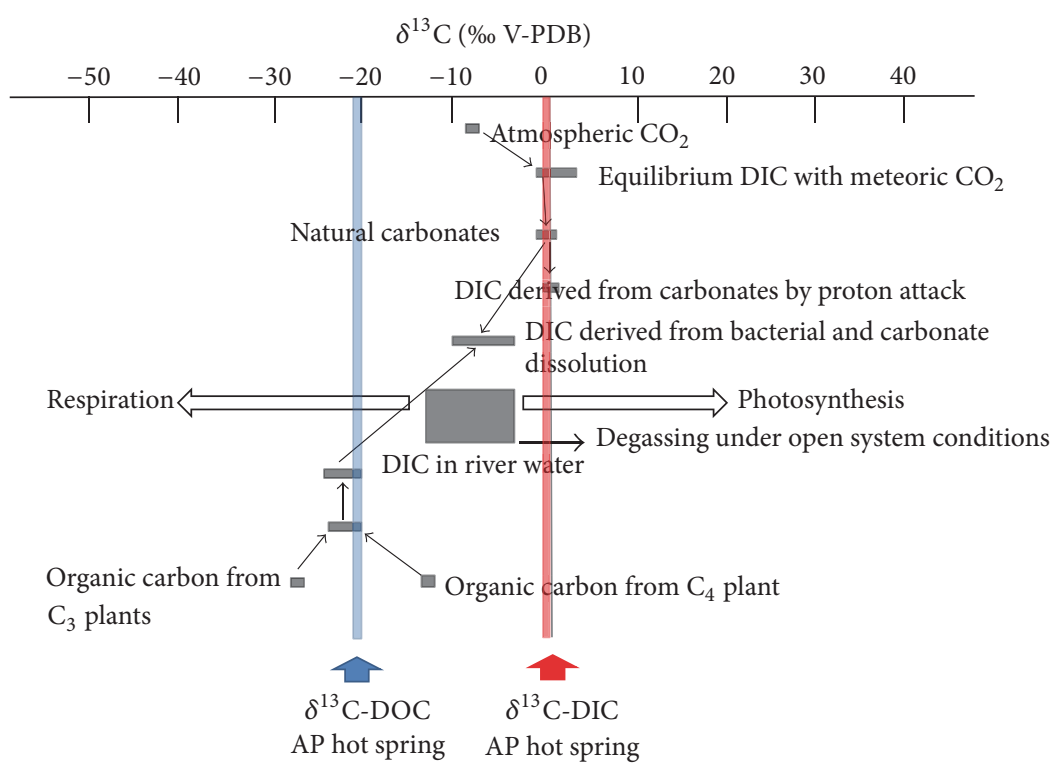

Figure 9: The $\delta^{13} \mathrm{C}$-DIC and $\delta^{13} \mathrm{C}$-DOC in AP hot spring.

systems. The very low amount of DOC in the AP spring $\left(3 \mathrm{mgL}^{-1}\right)$ with $\delta^{13} \mathrm{C}$-DOC value of $-21.4 \%$ VDPB probably originated from organics in the Sanganeh Formation.

\section{Conclusions}

According to geological, hydrogeochemical, and stable isotope studies the AP spring can be classified as a steam heated waters type. The main heat source for the high water temperature $\left(38^{\circ} \mathrm{C}\right)$ in this spring is the geothermal gradient. Using ${ }^{18} \mathrm{O}$ and ${ }^{2} \mathrm{H}$ the origin of the water is meteoric which has penetrated via deep faults/dissolution conduits in the study area. Meteoric waters percolated through the Tirgan marine carbonate formation (with $\delta^{13} \mathrm{C}$ content about $0 \%$ ) via faults and discharged from the AP spring after passing through underground karst systems. This can be confirmed by high amount of DIC and its enriched $\delta^{13} \mathrm{C}$ value $(-1.3 \%$ o VDPB). The deep circulation of water in this area can be inferred via high concentration of $\mathrm{HCO}_{3}, \mathrm{Ca}, \mathrm{Mg} ; \mathrm{CaSO}_{4}$ water type; thermogenic travertine and high amount of $\mathrm{CO}_{2}$ gas; and thermal anomaly as well. The region is tectonized and has many folds, such as Asiazow anticline which is the main recharge zone of the AP springs. According to Na-K geothermometry, modelling, and stable isotope analyses, the depth of the AP hot spring geothermal reservoir is estimated to be 4-5 kilometres with a temperature of about $150^{\circ} \mathrm{C}$. This great depth combined with the water type suggests a hypogenic karst system signature that needs more investigation.

\section{Competing Interests}

The authors declare that there is no conflict of interests regarding the publication of this paper.

\section{Acknowledgments}

The authors would like to thank Northern Khorasan Regional Water Company (NKRWC), Groundwater Research Center (GRC) of Ferdowsi University of Mashhad and Ottawa University geochemistry, and G. G. Hatch Stable Isotope laboratories for their help on sampling and sample analysis. They also thank Dr. Matt Herod for reviewing the manuscript and appreciate Mr. Asghari and Mr. Alizadeh's assistance during field work. Financial support was partially provided by NKRWC (CN: KNW89098).

\section{References}

[1] A. Shah-Beyg, Geology of Iran: Iranian Mineral and Warm Waters, Geological Survey of Iran, Tehran, Iran, 1993 (Persian).

[2] M. R. Ghafouri and S. R. Mortazavi, Hydrology, Tehran University Press, Tehran, Iran, 1995 (Persian).

[3] E. Barbier, "Nature and technology of geothermal energy: a review," Renewable and Sustainable Energy Reviews, vol. 1, no. 1-2, pp. 1-69, 1997.

[4] I. F. Barut, N. Erdogan, and E. Basak, "Hydrogeochemical evaluation of Western Anatolian mineral waters," Environmental Geology, vol. 45, no. 4, pp. 494-503, 2004.

[5] C. Dilsiz, J. M. Marques, and P. M. M. Carreira, "The impact of hydrological changes on travertine deposits related to thermal springs in the Pamukkale area (SW Turkey)," Environmental Geology, vol. 45, no. 6, pp. 808-817, 2004.

[6] N. Lambrakis and G. Kallergis, "Contribution to the study of Greek thermal springs: hydrogeological and hydrochemical characteristics and origin of thermal waters," Hydrogeology Journal, vol. 13, no. 3, pp. 506-521, 2005.

[7] A. S. L. R. Asem, "Mineral and hot spring of province of east Azarbayjan," Roshd Geol Magazine of Iran, vol. 14, pp. 21-25, 2008 (Persian). 
[8] H. Karimi and F. Moore, "The source and heating mechanism for the Ahram, Mirahmad and Garu thermal springs, Zagros Mountains, Iran," Geothermics, vol. 37, no. 1, pp. 84-100, 2008.

[9] S. Vellayati, Geography of Waters, University Jahad Press, Mashhad, Iran, 2009 (Persian).

[10] A. Salmanzadeh, C. Samavat, and M. T. Samadi, "Evaluation of environmental gamma Qynrjh, Eylandv and Moeilsouei hot springs," Medical Journal of Tabriz University of Medical Sciences, vol. 3, pp. 281-287, 2008 (Persian).

[11] T. Haile and T. A. Abiye, "The interference of a deep thermal system with a shallow aquifer: the case of Sodere and Gergedi thermal springs, Main Ethiopian Rift, Ethiopia," Hydrogeology Journal, vol. 20, no. 3, pp. 561-574, 2012.

[12] D. Todd, Groundwater Hydrology, Argosy Publishing, New York, NY, USA, 2005.

[13] K. T. McCarthy, T. Pichler, and R. E. Price, "Geochemistry of Champagne Hot Springs shallow hydrothermal vent field and associated sediments, Dominica, Lesser Antilles," Chemical Geology, vol. 224, no. 1-3, pp. 55-68, 2005.

[14] E. Sacchi, G. M. Zuppi, L. Pizzino, F. Quattrocchi, and S. Lombardi, "Fluid geochemistry as indicator of tectonically-related, deep water circulations in the Sardinian Rift-Campidano Graben (Italy): new insights from environmental isotopes," Aquatic Geochemistry, vol. 14, no. 4, pp. 301-319, 2008.

[15] L. R. Sekento, Geochemichal and Isotopic Study of the Menengal Geothermal Field, Kenya, Geothermal Training Programme, Reykjavik, Iceland, 2012.

[16] H. Mohammadzadeh, Source and Water Quality Investigation of "Ayüb Peighambar Hot Spring" by Hydrogeochemistry, Environmental Stable Isotopes, and Structural Geology Studies, Ferdowsi University of Mashhad, Ground Water Research Centre (GRC), Mashhad, Iran, 2014 (Persian).

[17] AqQA Software. Version 1.1.1, Prairie City Computing, Inc., 2006, http://www.aqqa.com.

[18] C. A. Hill, Geology of Carlsbad Cavern and Other Caves in the Guadalupe Mountains, New Mexico and Texas, New Mexico Bureau of Mines and Mineral Resources Bulletin 117, New Mexico Bureau of Mines and Mineral Resources, Sante Fe, NM, USA, 1987.

[19] S. J. Egemeier, "Cavern development by thermal waters," National Speleological Society Bulletin, vol. 43, no. 2, pp. 31-51, 1981.

[20] A. Afshar-Harb, Geology of Kopet-Dagh, Geological Survey of Iran, Tehran, Iran, 1994 (Persian).

[21] AQ.QA 2006. Aq.QA Software,. Version 1.1.1 ed.

[22] W. F. Giggenbach, "Chemical techniques in geothermal exploration, application of geochemistry in geothermal reservoir development (Co-ordinator D'Amore, F.)," in Geothermal Energy Systems: Exploration, Development, and Utilization, E. Huenges and P. Ledru, Eds., pp. 119-144, UNITAR/UNDP Centre on Small Energy Resources, Rome, Italy, 1991.

[23] Z. Liu, M. Zhang, Q. Li, and S. You, "Hydrochemical and isotope characteristics of spring water and travertine in the Baishuitai area (SW China) and their meaning for paleoenvironmental reconstruction," Environmental Geology, vol. 44, no. 6, pp. 698704, 2003.

[24] M. Kazemi and H. Mohammadzaeh, "Investigation on geothermal energy source in North Khorasan proviance, NE of Iran (Ayub and Shafa hot spring)," in Proceedings of the National Symposium of Clean and Renewable Energy, 2013 (Persian).
[25] M. Kompani-Zare and F. Moore, "Chemical thermometry and origin of the Dalaki mineral springs, Bushehr Province, Iran," Journal of Hydrology New Zealand, vol. 40, no. 2, pp. 189-204, 2001.

[26] SUNA, "Renewable energy ministry of Iran," 2001, http://www suna.org.ir/fa/geothermal.

[27] R. O. Fournier, "Water geothermometers applied to geothermal energy," in Application of Geochemistry in Geothermal Reservoir Development, F. D’Amore, Ed., pp. 37-69, UNITAR/UNDP, Rome, Italy, 1991.

[28] D. M. Allen, S. E. Grasby, and D. A. Voormeij, "Determining the circulation depth of thermal springs in the southern Rocky Mountain Trench, south-eastern British Columbia, Canada using geothermometry and borehole temperature logs," Hydrogeology Journal, vol. 14, no. 1-2, pp. 159-172, 2006.

[29] S. Arnórsson, E. Gunnlaugsson, and H. Svavarsson, "The chemistry of geothermal waters in Iceland III: chemical geothermometry in geothermal investigations," Geochimica et Cosmochimica Acta, vol. 47, no. 3, pp. 567-577, 1983.

[30] W. F. Giggenbach, "Geothermal solute equilibria. Derivation of Na-K-Mg-Ca geoindicators," Geochimica et Cosmochimica Acta, vol. 52, no. 12, pp. 2749-2765, 1988.

[31] A. Mohammadi, "Investigation hydrogeochemical and balneotrapy of Ayub hot spring (north Khorasan)," in Proceedings of the 15th Symposium of Geological Society of Iran, Tarbiat Moalem University, Tehran, Iran, 2011 (Persian).

[32] J. M. Marques, P. M. Carreira, J. E. Marques et al., "The role of geosciences in the assessment of low-temperature geothermal resources (N-Portugal): a review," Geosciences Journal, vol. 14, no. 4, pp. 423-442, 2010.

[33] I. Clark and P. Fritz, Environmental Isotopes in Hydrogeology, CRC Press, Boca Raton, Fla, USA, 1997.

[34] A. Alizadeh, The Principles of Applied Hydrology, University of Emam Reza Press, Mashhad, Iran, 2006 (Persian).

[35] Z. Shangguan, J. Du, W. Zang, J. Wang, L. Kong, and S. Gao, "Modern hot spring geochemistry at the Tanlu fault and Jiaoliao block in eastern China," Science in China, Series D: Earth Sciences, vol. 41, no. 1, pp. 87-94, 1998.

[36] H. Mohammadzadeh and Z. Shirnejad, "Evaluation of dissolved inorganic and organic carbon concentrations (DIC, DOC) and their isotopic composition $\left(\delta^{13} \mathrm{C}\right.$-DOC, $\delta^{13} \mathrm{C}$-DIC) in water resources of Karde catchment area (North of Mashhad)," Journal of Water and Wastewater, vol. 26, no. 3, pp. 81-92, 2015 (Persian). 

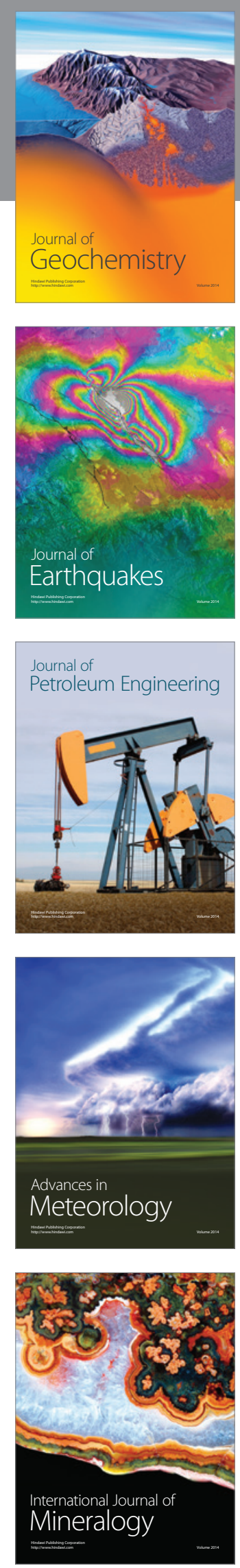
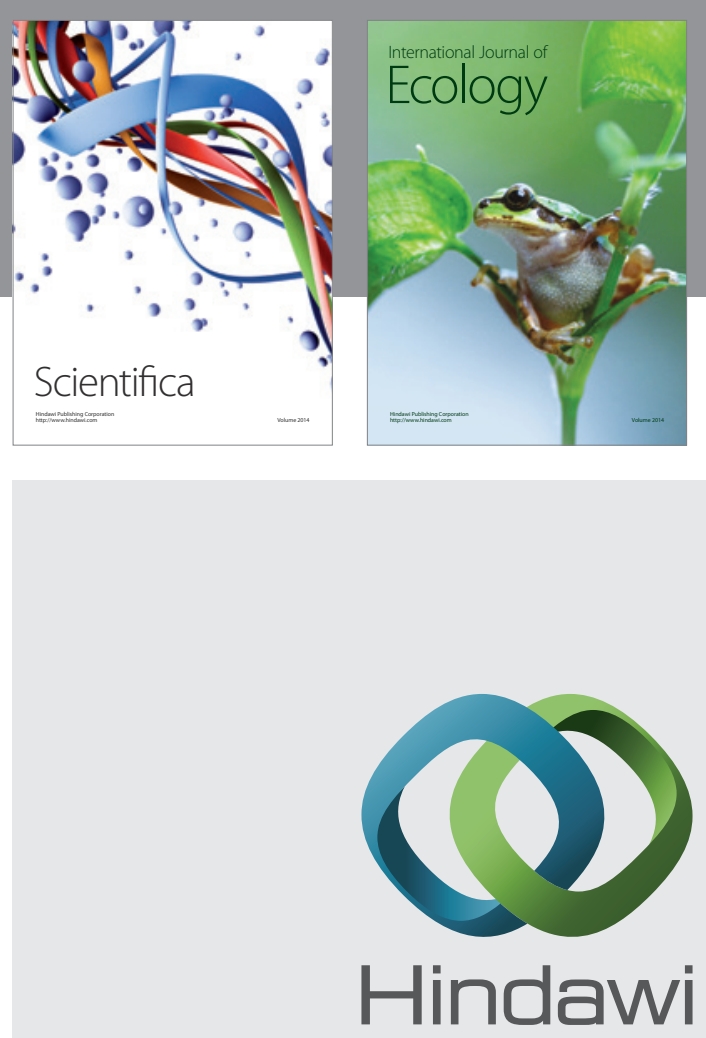

Submit your manuscripts at

https://www.hindawi.com
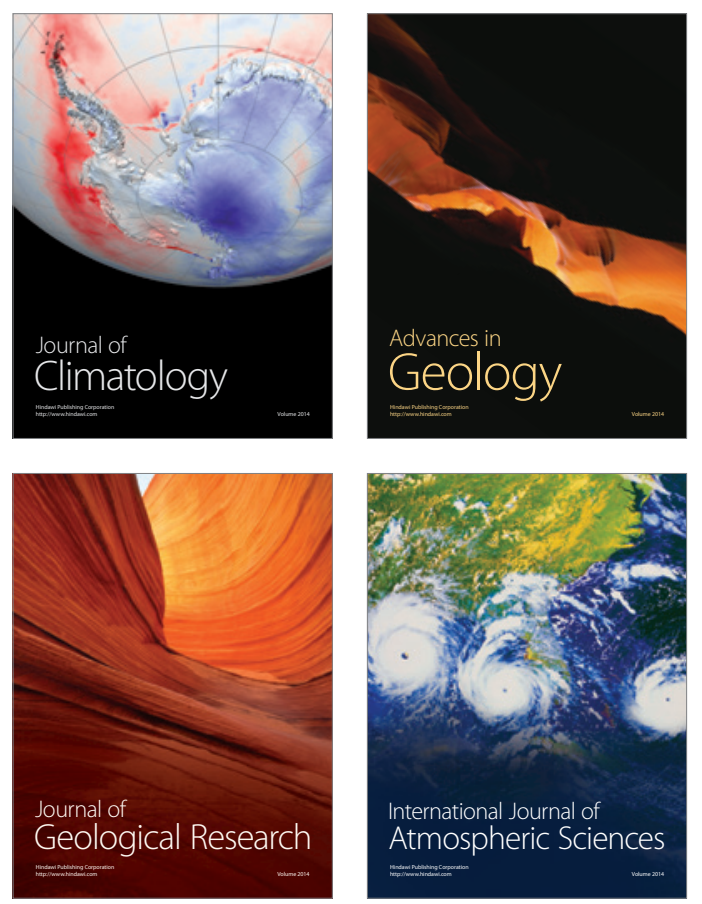

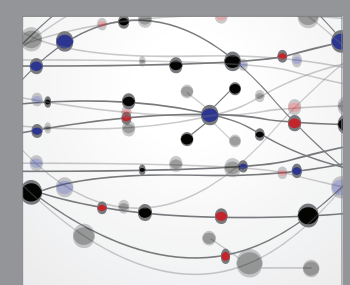

The Scientific

\section{World Journal}
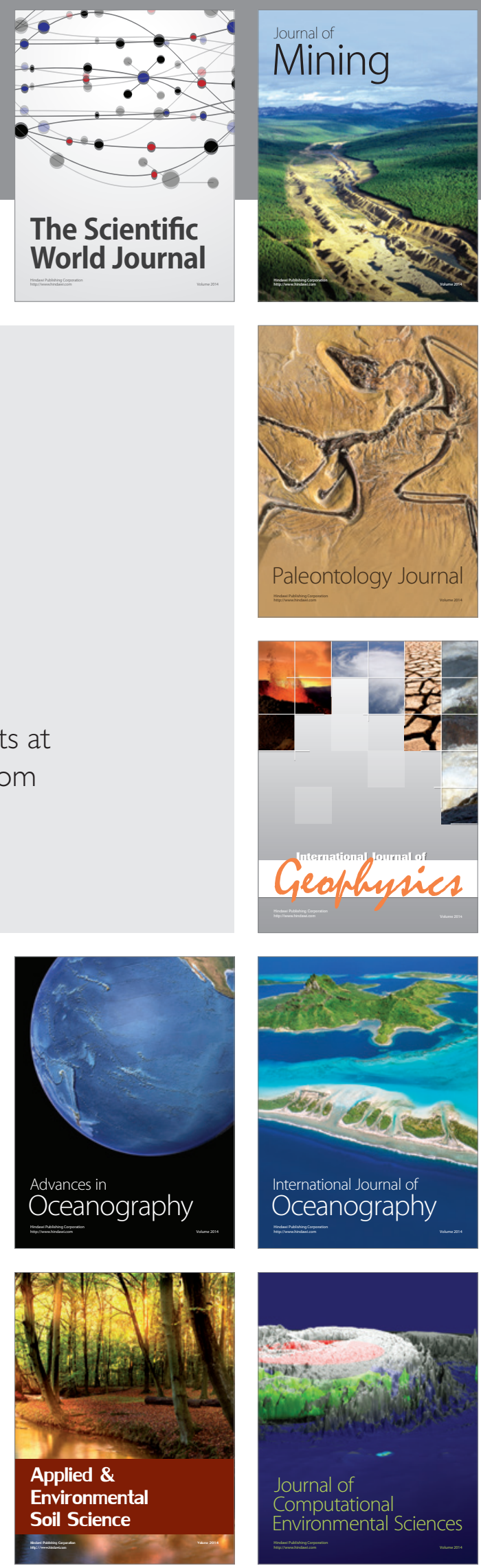